\title{
Corrigendum: Interleukin-12 bypasses common gamma-chain signalling in emergency natural killer cell lymphopoiesis
}

Isabel Ohs, Maries van den Broek, Kathrin Nussbaum, Christian Münz, Sebastian J. Arnold, Sergio A. Quezada, Sonia Tugues \& Burkhard Becher

Nature Communications 7:13708 doi: 10.1038/ncomms13708 (2016); Published 16 Dec 2016; Updated 4 Apr 2017

The financial support for this Article was not fully acknowledged. The acknowledgements should have included the following:

The European Community FP7 grant no. 602239 (ATECT).

\footnotetext{
(c) This work is licensed under a Creative Commons Attribution 4.0 International License. The images or other third party material in this article are included in the article's Creative Commons license, unless indicated otherwise in the credit line; if the material is not included under the Creative Commons license, users will need to obtain permission from the license holder to reproduce the material. To view a copy of this license, visit http://creativecommons.org/licenses/by/4.0/
}

(C) The Author(s) 2017 